\title{
ENTRE DESDÉM TEÓRICO E APROVAÇÃO NA PRÁTICA: OS MÉTODOS CLÁSSICOS DE INTERPRETAÇÃO JURÍDICA
}

\section{RESUMO}

BOA PARTE DOS AUTORES BRASILEIROS QUESTIONA A UTILIDADE DOS ELEMENTOS METODOLÓGICOS TRADICIONAIS DA INTERPRETAÇÃO JURÍDICA, CUJA IMPORTÂNCIA ESTÁ SENDO REDESCOBERTA EM outros países como a Alemanha. Apesar da Rejeição teórica, OS APLICADORES DO DIREITO CONTINUAM A SE VALER DOS MÉTODOS CLÁSSICOS NA PRÁTICA. A PRÓPRIA INTERPRETAÇÃO É GUIADA PELAS ETAPAS MENTAIS DESTES MÉTODOS, AINDA QUE A ESCOLHA DECISIVA ENTRE ELES SEJA INFLUENCIADA PELA PRÉ-COMPREENSÃO PESSOAL DO APLICADOR DA LEI SOBRE UMA SOLUÇÃO JUSTA DO CASO. ASSIM, O USO DOS QUATRO CÂNONES NA PRODUÇÃO DA DECISÃO JURÍDICA DEPENDE DE UMA ARGUMENTAÇÃO RACIONAL QUE OBSERVE AS "REgRAS DE ARTE" DA COMUNICAÇÃO JURÍdICA. A EXPECTATIVA SOCIAL DE UMA VINCULAÇÃO ESTRITA ENTRE DECISÃO JUDICIAL E TEXTO LEGAL LEVA A UM TIPO DE INTERPRETAÇÃO QUE TEM AS DIRETIVAS METÓDICAS TRADICIONAIS COMO SEUS PRINCIPAIS INSTRUMENTOS. EMBORA ELES NÃO LEVEM A DECISÕES CIENTIFICAMENTE VERDADEIRAS, DEVE SER RECONHECIDA A SUA IMPORTÂNCIA NO EXERCÍCIO DO RACIOCÍNIO JURÍDICO.

\section{PALAVRAS-CHAVE}

INTERPRETAÇÃO JURÍDICA; ElEMENTOS METÓdICOS; CÂNONES tRadicionaIS; PRÉ-COMPREENSÃo; JustificatiVA dA dECISÃo.

\section{ABSTRACT}

A GOOD PART OF BRAZILIAN AUTHORS QUESTIONS THE USEFULNESS OF THE TRADITIONAL METHODIC ELEMENTS OF LAW INTERPRETATION WHOSE IMPORTANCE IS BEING REDISCOVERED IN OTHER COUNTRIES LIKE GERMANY. IN SPITE OF THEORETIC REJECTION, THE LAW APPLYING OFFICIALS CONTINUE TO MAKE USE OF THE CLASSICAL METHODS IN PRACTICE. INTERPRETATION ITSELF IS GUIDED BY THE MENTAL STAGES OF THESE METHODS, ALTHOUGH THE DECIDING CHOOSE BETWEEN THEM IS INFLUENCED BY THE LAW APPLIERS PERSONAL PRE-COMPREHENSION ABOUT A FAIR SOLUTION OF THE CASE. THUS, THE USE OF THE FOUR CANONS IN FORENSIC DECISIONMAKING DEPENDS ON THE FACTORS OF RATIONAL ARGUMENTATION WHICH OBEYS TO THE "RULES OF ART" OF JURISTIC COMMUNICATION. SOCIAL EXPECTATION OF A STRICT CONNECTION BETWEEN JUDICIAL DECISION AND LEGAL TEXT LEAD TO A TYPE OF INTERPRETATION WHICH HAS THE FOUR TRADITIONAL METHODIC DIRECTIVES AS ITS MAIN INSTRUMENTS. EVEN THOUGH THEY DO NOT LEAD TO SCIENTIFICALLY TRUE ANSWERS, ONE MUST RECOGNIZE THEIR IMPORTANCE FOR EXERCISING JURISTIC REASONING.

\section{KEYWORDS}

JURISTIC INTERPRETATION; METHODICAL ELEMENTS; TRADITIONAL CANONS; PRE-COMPREHENSION; JUSTIFICATION OF DECISION.

\section{INTRODUÇÃO}

Pretende-se demonstrar neste trabalho que os tradicionais métodos de interpretação jurídica (literal, sistemático, histórico e teleológico) continuam sendo imprescindíveis pontos de referência na aplicação diária do Direito (Civil, Penal, Administrativo etc.), inclusive o Constitucional. Entretanto, enfatize-se, desde o início, que não se ignoram 
aqui os vícios e abusos de uma interpretação jurídica fixada apenas nos seus métodos tradicionais, aos quais já se atribuiu no passado uma pretensa exatidão científica que nunca tiveram e jamais terão. $\mathrm{Na}$ verdade, os quatro cânones não representam "métodos" próprios, senão apenas regras, diretivas, técnicas, meios, critérios, argumentos, princípios ou elementos metódicos para a correta interpretação e aplicação das normas jurídicas (VELASCO; GUTIÉRREZ, 2011, p. 32 s.).

No Brasil, a hermenêutica jurídica possui traços peculiares. Durante o governo militar, o estudo do Direito nas faculdades e a produção acadêmica em geral foi marcadamente positivista e técnico-formal. Após o fim do regime autoritário, tentou-se resgatar a dimensão teórica e do Direito, enfatizando-se os seus aspectos filosóficos, sociológicos, políticos, linguísticos, antropológicos etc. Até hoje, muitos autores parecem estar inspirados pela reação contra uma interpretação meramente "dogmática" e "formalista" do fenômeno jurídico (MADEIRA FILHO, 2002, p. 50 s.), esquecendo que "reconhecer, interpretar e aplicar a norma jurídica válida exige referências cognitivas e capacitação profissional muito diversas dos planos de observação da sociedade ocupados por [...] filósofos ou sociólogos do direito" (CAMPILONGO, 2012, p. 124).

Ao mesmo tempo, a Teoria do Direito de outros países está passando por uma reabilitação dos cânones clássicos, reconhecendo-se a sua importância e utilidade para construir uma tradição e racionalidade própria no âmbito da decisão jurídica. ${ }^{1}$ Esta tendência é especialmente forte na doutrina jurídica contemporânea da Alemanha, que forma a base teórica de referência deste artigo.

Poucos livros brasileiros de introdução ao Direito atribuem ao tema da metódica de interpretação jurídica um espaço que corresponda a sua importância prática. Entre os autores que aprofundam a questão, há alguns que nem mencionam os elementos metódicos tradicionais ou lhes reservam um espaço mínimo. ${ }^{2}$ Outros os questionam fortemente (v.g., GRAU, 2009, p. 108 s.) ou até rechaçam categoricamente a utilidade dos cânones de interpretação para a aplicação coerente das normas jurídicas (v.g., STRECK, 2011, p. 136 ss.). Até hoje, muitos consideram os métodos "mera fachada" ou "álibi teórico" (WARAT, 1994, p. 88 s.), servindo apenas para esconder os verdadeiros motivos (ideológicos) da decisão. Na área do Direito Constitucional brasileiro, várias obras quase ignoram ou negam a utilidade dos métodos clássicos para a exegese da Lei Maior (v.g., MENDES; COELHO; BRANCO, 2008, p. 100 s.); poucas reconhecem a sua importância para a construção de uma decisão correta (v.g., BARROSO, 2010 , p. 291 ss.). ${ }^{3}$

No entanto, o desenvolvimento contínuo da interpretação jurídica na base de seus critérios metódicos tradicionais representa uma tarefa muito mais difícil do que a pretensiosa recusa total deles. Não faltam programas e projetos científicos abstratos e sofisticados referentes à metodologia do Direito cujas formulações deixam muitas dúvidas sobre a sua utilidade para o trabalho prático da aplicação das normas. A postura cética e extremamente crítica em relação aos cânones clássicos de interpretação, 
que até hoje domina os debates acadêmico-doutrinários no Brasil (hermenêuticos filosóficos, kelsenianos, realistas, analíticos da linguagem, entre outros), dificilmente tem atingido os operadores das profissões jurídicas do País, os quais, em geral, acreditam de maneira pragmática que as regras metódicas tradicionais "funcionam adequadamente para 'demonstrar' a verdade de posturas ou teses de direito” (MEDINA, 2011, p. 165).

A consequência dessa orientação exageradamente crítica em relação aos métodos clássicos por parte da doutrina jurídica nacional leva a um estado permanente de "esquizofrenia metodológica” daqueles profissionais do Direito que também estão ligados à academia: em sala de aula, eles aceitam ou até defendem (como professores ou alunos de cursos de pós-graduação stricto sensu) a impossibilidade da estruturação racional e/ou metódica do processo da interpretação jurídica; já no exercício prático de sua profissão, confiam no uso dos elementos metódicos tradicionais, empregando-os para solucionar os problemas que surgem nos casos concretos.

\section{Diretivas CONSTITUCIONAIS PARA A INTERPRETAÇÃO JURÍDICA E A SUA METÓDICA}

A ciência do Direito é eminentemente pragmática e orientada a decisões práticas (cf. FERRAZ JÚNIOR, 1980, p. 68 ss., 87 ss.), o que torna imprescindível que ela mantenha sempre estreito contato com a realidade social. Na visão pragmática, há uma ligação direta entre o conhecimento científico e o seu fim: não é decisiva a dedução correta a partir de fundamentos seguros, mas a comprovação da utilidade na prática (CATÃO, 2007, p. 23 ss.).

No século XIX, o método científico era visto como um tipo de catalisador que purificava o objeto Direito, jogando "a luz da racionalidade no escuro da falta de lógica e da contradição” (SCHILD, 1982, p. 415 s.). O intérprete saía de cena e tornava-se mera ferramenta, como se ele atuasse no interesse do próprio método, que garantia a isenção valorativa da ciência. Nos países do civil law, o controle das interpretações mediante objetivação dos métodos, transformados em "regras de arte escolarizadas" para produzir decisões jurídicas, também contribuiu bastante para assegurar a liberdade dos juízes em relação às instâncias políticas (ESSER, 1972, p. 123 s.).

Ao contrário da interpretação de obras de arte, filmes, livros etc., a jurídica acontece em um ambiente institucional especializado. A interpretação de um texto jurídico pretende gerar obrigatoriedade, o que restringe as práticas nesse âmbito; não "vale qualquer coisa" (anything goes). Leituras muito subjetivas, surpreendentes e alternativas, que na literatura ou música podem despertar elogios, no Direito devem ser evitadas para preservar a previsibilidade das decisões e a segurança das expectativas. Por isso, a metódica jurídica não pode ser reduzida a questões da linguagem, comunicação ou compreensão (MÜLLER; CHRISTENSEN, 2002, p. 28 s.). 
A aplicação de normas legais não visa apenas pôr um fim aos conflitos e litígios entre partes, mas pretende produzir decisões corretas e justas, as quais a própria sociedade espera da ordem jurídica e das suas instituições. Essa expectativa de correição normativa influencia o aplicador do Direito em relação à apresentação de sua decisão, que deve gerar aceitação e convencimento a respeito de sua correição e justeza (MORLOK, 2012, p. 207 s.).

É sabido, contudo, que o emprego das quatro diretivas metódicas clássicas na interpretação do Direito não garante um resultado correto. Os cânones não formam um "método" no sentido de que a segurança dos passos mentais seja garantida ou que a sequência dos argumentos possa ser fixada com antecedência (LUHMANN, 1995, p. 345). Neste ponto, assiste razão a Kelsen (1962, p. 290) quando alega que "todos os métodos de interpretação até ao presente elaborados conduzem sempre a um resultado apenas possível, nunca a um resultado que seja o único correto”. Por isso, qualquer análise científica que indague sobre os motivos pela tomada de uma decisão jurídica deve investigar também as outras etapas da formação do juízo. No entanto, a prática diária da aplicação do Direito pelos órgãos estatais exige uma fundamentação objetiva e socialmente aceita das decisões, que mantenha a retórica da vinculação estrita entre o texto da lei e o resultado de sua aplicação pelo agente público, ainda que este vínculo, no fundo, seja uma ficção.

A metódica 4 jurídica deve ser analisada também a partir de uma reflexão sobre a produção das decisões do Poder Público às normas jurídicas vigentes que corresponda às exigências do Estado Democrático de Direito: a vinculação dos agentes estatais é integrante imprescindível da estrutura de legitimação deste. Toda atividade estatal fica sujeita à lei, expressão da vontade geral e materializada em atos formalmente criados pelos órgãos da representação popular (SILVA, 2003, p. 419 ss.). A Constituição de 1988, além de consagrar a separação dos poderes estatais, fixa este princípio fundamental no seu art. $5^{\circ}$, II, segundo o qual "ninguém será obrigado a fazer ou deixar de fazer alguma coisa senão em virtude de lei”. Nesse sentido, não é exagero afirmar que, também no Brasil, "questões metodológicas são questões constitucionais" (RÜTHERS, 1999 , p. 397 ss.).

A vinculação legal dos agentes públicos somente pode ser estabelecida racionalmente por meio de uma metódica que garanta que casos iguais sejam tratados de maneira igual, mantendo-se a isonomia na aplicação do Direito. Aqui não faz muito sentido a afirmação apodítica “Todo caso é diferente”, visto que são as próprias regras jurídicas que determinam quais aspectos de cada caso real são relevantes para a decisão (NEUMANN, 2001, p. 244 s.; RÖHL; RÖHL, 2008, p. 604 s.).

Os órgãos públicos que aplicam as normas democraticamente postas estão vinculados ao conteúdo destas, o qual devem reproduzir na maior medida possível. Para tanto, é preciso recapitular o caminho mental que levou o julgador à decisão concreta, tornando possível que outros andem na mesma senda (methodos = "caminho de ir atrás"). Além 
disso, o objetivo do método é reduzir a subjetividade do intérprete, possibilitar o seu autocontrole e "direcionar o seu agir para caminhos previsíveis" (SCHMITT GLAESER, 2004, p. 139 ss.; STRAUCH, 2001, p. 200 s.). Para tanto, as etapas da aplicação da lei devem ser reveladas para assegurar uma relação sindicável de dedução entre a norma abstrata editada pelo Legislativo e a inferência concreta do Judiciário. O próprio desenvolvimento dos métodos jurídicos é fruto da discussão sobre o tamanho adequado dos espaços de avaliação a serem concedidos aos aplicadores do Direito (RÜTHERS, 1999 , p. 369 s.).

$\mathrm{Na}$ interpretação da Constituição, a importância dos métodos tradicionais, sem dúvida, diminui. O texto da Lei Maior regulamenta relações políticas e sociais, o que o torna, segundo Bonavides (2006, p. 461), sujeito a um "influxo político considerável, senão essencial, o qual se reflete diretamente sobre a norma, bem como sobre o método interpretativo aplicável". Todavia, o autor deixa claro que não defende "uma técnica interpretativa especial para as leis constitucionais" e tampouco pretende "preconizar os meios e regras de interpretação que não sejam aquelas válidas para todos os ramos do Direito, cuja unidade básica não podemos ignorar nem perder de vista [...]”. Na mesma linha, Canotilho (1997, p. 1084 ss.) entende que a interpretação da Constituição deve ser efetuada mediante um conjunto de métodos reciprocamente complementares, entre os quais está o "método jurídico” clássico.

Além do mais, a doutrina brasileira adotou vários (pretensos) "princípios de interpretação constitucional” (unidade da constituição, concordância prática, máxima efetividade etc.), dos quais alguns são pouco relevantes porque "em nada se diferenciam dos cânones tradicionais de interpretação” (SILVA, 2005, p. 121). Entretanto, é exagerada a crítica de Forsthoff (1961), que defendeu uma interpretação da Lei Maior restrita aos cânones tradicionais, porquanto temia que os métodos abertos como a tópica levariam à dissolução total do caráter jurídico da Constituição.

Peter Häberle (1978, p. 73), que muito influenciou a consolidação teórica da moderna hermenêutica constitucional, constata que "interpretação aberta integra os métodos interpretativos tradicionais", impondo apenas a sua "abertura". Apesar de defender um procedimento interpretativo plural da Constituição que inclua diversos atores e seja orientado pela realidade, publicidade e consideração das consequências das decisões para o bem comum, o autor não despreza os princípios e métodos interpretativos clássicos, os quais, para ele, “preservam o seu significado”, assumindo, contudo, a nova função de "'filtros' sobre os quais a força normatizadora da publicidade [...] atua e ganha conformação” (HÄBERLE, 1997, p. 43 s.).

\section{A NECESSÁria CONCILIAÇÃo DA TEORIA COM A PRÁXIS DA INTERPRETAÇÃO E APLICAÇÃO DO DIREITO; A RACIONALIDADE JURÍDICA}

Segundo Kriele (1976, p. 21 ss.), a metodologia jurídico-científica sempre tem 
procurado desenvolver padrões que permitam um controle dos aplicadores do Direito referente a seu acerto ou erro na utilização dos métodos. Entretanto, a práxis costumaria seguir o seu próprio caminho, uma vez que "ela se deixa elogiar, repreender, etiquetar, mas pouco influenciar”. Para ele, a teoria jurídica não reflete suficientemente $o$ que a práxis efetivamente faz, como ela o faz e, sobretudo, por que o faz assim e não de forma diferente. Em vez de reclamar da ignorância, arrogância ou lerdeza da práxis, faria mais sentido indagar se muitos argumentos teóricos não são simplesmente inúteis para o trabalho prático. A divisão teoria/prática não deveria, portanto, ser entendida como separação entre categorias profissionais (pesquisadores, juízes, procuradores, advogados, consultores etc.), mas como "ideia teórica inadequada daquilo que se faz na prática" do Direito (KRIELE, 1976, p. 43 s.). ${ }^{5}$

É duvidoso querer exorcizar o pretenso mal dos métodos jurídicos tradicionais, apesar de que estes continuam a ser amplamente utilizados na prática da Administração Pública e dos tribunais. O seu emprego real não se dá como consulta a uma lista fixa, feito um roteiro para testar diferentes resultados, mas na forma do enveredar (até inconsciente) de diferentes caminhos ou "sequências de raciocínio", às quais o intelecto humano recorre para solucionar certo problema e produzir uma decisão. Ao mesmo tempo, é público e notório que a prática judicial se acha cheia de pecados metódicos, não somente no Brasil. Em toda parte, há juízes que não justificam as suas sentenças adequadamente por não considerar certos elementos metódicos tradicionais, que poderiam (ou deveriam) ter levado a uma decisão diferente (HASSEMER, 2007, p. 140 ss.).

Hassemer (2007, p. 119 ss.) admite que, ainda que o sistema do Direito codificado determine a vinculação estrita do juiz à lei posta, a efetividade dos métodos interpretativos é restrita, visto que já a sequência de sua apresentação pode consistir em uma estratégia para legitimar o resultado. Mesmo assim, ele considera que os cânones, além de expressar "as melhores tradições do sonho por uma justiça no Estado de Direito" que seja vinculada às decisões de um legislador eleito, são "documentos de um sério e erudito radicalismo na procura de um apoio firme para a compreensão e interpretação de leis" (ob. cit., p. 124). Por isso, a metodologia jurídica deveria observar melhor a prática forense, a qual ela não consegue "acertar, ordenar ou controlar" por ser dominada por "programas informais”, regidos por rotinas, hábitos e saberes funcionais, isto é, modelos pragmáticos do trabalho com a lei, "ordenados pelo pensar, ler, compreender, agir, escrever e falar profissional", que variam de acordo com o ramo do Direito e possuem cenários diferenciados de obter e justificar as decisões (HASSEMER, 2007, p. 141 ss.). Este quadro observado na Alemanha não diverge muito da situação brasileira.

A viabilidade de uma metódica deve ser demonstrada, sobretudo, na solução dos casos comuns do dia a dia do trabalho jurídico. Há, porém, uma forte tendência da teoria de se referir apenas a casos excepcionais ou "difíceis". No caso normal, o limite gramatical do termo legal permite uma subsunção relativamente tranquila. $O$ fato de não 
existir um limite linguístico rígido não invalida a ideia de uma vinculação pela linguagem. As exageradas críticas que alegam a absoluta contingência e imprevisibilidade da interpretação de textos legais levam à descrença de muitos profissionais em relação a seu ofício, abrindo, inclusive, os portões para julgadores nada neutros. Estes se aproveitam do discurso da falta de vinculação do intérprete à lei para perseguir os seus fins políticos, ideológicos ou econômicos (HOCHHUT, 2001, p. 229 s.).

A ciência do Direito, em vez de se sobrecarregar com a pretensão de influenciar o próprio processo de produção da decisão forense, dever-se-ia limitar a cultivar a capacidade de controlar se esta, uma vez tomada, pode ser justificada e apresentada racionalmente. Nessa tarefa, os meios metódicos tradicionais não levam "à verdade”, mas servem como boas razões no processo discursivo de uma argumentação. O que é materialmente correto não pode ser fixado e "conhecido" unilateralmente, mas deve ser produzido de maneira intersubjetiva e, assim, reconhecido. O processo da tomada da decisão jurídica é guiado por diferentes elementos, que se integram e complementam, para fundamentar a racionalidade do resultado em vários aspectos: a técnica da metodologia clássica, o raciocínio lógico (para evitar contradições) e, sobretudo, a valoração argumentativa que leva à ponderação entre bens e interesses (MASTRONARDI, 2009, p. 99 ss.).

A própria racionalidade jurídica nasce, portanto, em uma "consciência institucional" (não individual), segundo as regras de um processo organizado pela divisão do trabalho. O essencial desta racionalidade não é o "verdadeiro", mas o "certo" e "seguro" que surge no agir recíproco nas relações sociais e no qual se pode confiar nas relações com os outros, justamente porque cada um age desta forma por reconhecer tal comportamento como o "correto" (SCHELSKY, 1980, p. 35).

A linha mais convincente da metodologia jurídica contemporânea pretende reconstruir o procedimento por meio do qual o intérprete chega a uma decisão considerada justa e/ ou correta, fundamentando-a racionalmente e abrindo a ciência jurídica à dimensão da razão argumentativa. Para que uma interpretação não apareça como mero arbítrio, é preciso que ela se baseie em "reflexões comunicáveis e claras" (ZACCARIA, 2004, p. 27 ss.). Em relação à hermenêutica geral, a racionalidade do Direito é "tecnicamente intensificada”, porque dispõe de elementos para avaliar a correção de uma interpretação. E, ainda que os critérios jurídico-racionais não sejam quantitativamente aferíveis, senão objeto de apreciação valorativa, eles criam uma rede mais ou menos densa de motivos que permite criticar ou justificar decisões jurídicas. Uma sentença normativamente correta sempre exige que, entre as fases da pré-compreensão e a decisão, haja uma fase de verificação metódica (MASTRONARDI, 2001, p. 175 s.).

A decisão jurídica não pretende apenas estar em conformidade com a lei, mas ser, ao mesmo tempo, objetivamente correta ("pretensão de correção"). É notório que o jurista deve se orientar nas normas jurídicas postas; estas, no entanto, podem não contemplar certas situações, ser tecnicamente ultrapassadas ou não corresponder mais às 
convicções contemporâneas a respeito de uma solução justa. Neste dilema da pergunta em que medida o operador jurídico se deve orientar na disposição legal ou no critério da retidão material, seria ingênuo assumir uma posição do “tudo ou nada”. Somente as duas exigências em conjunto, a da legalidade da decisão e a de sua correção objetiva, formam o sistema coordenado da argumentação jurídica (NEUMANN, 2008, p. 84 s.).

A escolha de determinado sentido para um conceito legal atende ao fim de solucionar um problema prático, em uma maneira materialmente adequada e justa, que deve ser arrazoada. A própria interpretação jurídica constitui um processo argumentativo de escolha, orientado por diferentes objetivos. A justificação da decisão possui um lado formal, ligado a certas regras de raciocínio e da lógica, e um lado consensual, quando busca alcançar concordância sobre as valorações que influenciam a interpretação e as ideias finalísticas sobre as consequências. Os critérios tidos por racionais, contudo, muitas vezes também deixam espaços para ponderação e escolha (ZIPPELIUS, 1996 , p. 391 s.). Revela-se, portanto, que a argumentação jurídica "é estruturada racionalmente, mas não estritamente determinada por aspectos racionais. Enquanto questões de valoração não podem ser mais dissolvidas racionalmente, o pensamento argumentativo somente pode aspirar a gerar o consenso mais abrangente possível” (ob. cit., p. 399).

É evidente que, para cumprir a sua pretensão de produzir decisões corretas, o Direito se abre em relação a padrões morais, sujeitos a valorações pessoais daquele que o aplica. Essa abertura é inevitável, mas pode ser aceita somente em virtude da existência de regras argumentativas do método jurídico que evitam que ela leve à arbitrariedade e a uma perda total de segurança jurídica (ALEXY, 2005, p. 168). O Direito, na verdade, sempre tem funcionado apesar de inúmeras indefinições semânticas dos conceitos que emprega. "O que importa realmente é certa 'aptidão prática' dos procedimentos argumentativos", os quais devem ser, sobretudo, "adequados a garantir a possibilidade de disputa em torno de certos estados de coisas futuras ou presentes, que se possam querer preservar" (CASTRO JÚNIOR, 2009, p. 21). Assim, qualquer sentença necessita de justificação, não apenas para legitimá-la para fora, mas para possibilitar a medição e avaliação de sua racionalidade, coerência, retidão e correção. O tipo de sentença jurídica que resiste ao cumprimento discursivo de sua "pretensão de validade" é justamente aquele que não se deixa justificar objetivamente, por meio de argumentos racionais (HAVERKATE, 1977, p. 195 ss.).

\section{OS QUATRO ELEMENTOS METÓDICOS CLÁSSICOS}

DA INTERPRETAÇÃO JURÍDICA: CONTEÚDO E CRÍTICAS

$\mathrm{Na}$ prática da ciência do Direito dos países democráticos ocidentais, os quatro clássicos métodos de interpretação (gramatical, sistemático, histórico e teleológico) estão onipresentes até os dias de hoje; países como a Áustria, a Suíça e a Itália os positivaram 
nos seus Códigos Civis. Três dos referidos métodos ganharam o status de cânones com Savigny, ${ }^{6}$ em meados do século XIX, que os chamava de elementos de interpretação, para destacar que não se tratava de "métodos" alternativos e hierarquizados, antes critérios a serem sempre considerados no exercício do labor interpretativo, os quais, porém, podem ganhar um peso diferenciado, de acordo com o caso, os fatos e as normas (MORLOK, 2012, p. 179 s.). Seja lembrado, contudo, que muitos autores já falam de cinco (ou até mais) cânones interpretativos clássicos, incluindo neste rol o elemento da comparação com as normas, instituições, doutrinas e decisões judiciais estrangeiras (“método comparativo").

A maior objeção a estes aspectos metódicos sempre tem sido o fato de que eles não são capazes de abrir um caminho seguro para o fim perseguido, estando sempre sujeitos a uma escolha por parte do intérprete. É verdade que os cânones não são determinantes para a decisão do aplicador da lei a respeito da escolha do elemento preferível para o caso concreto. Este depende de sua pré-compreensão sobre a solução correta, uma expectativa de correção/retidão que também é guiada pela consideração das consequências da decisão e por sua aceitabilidade social. Critica-se que estes fatores subjacentes, que de forma efetiva determinam a aplicação da norma, normalmente ficam escondidos.

Todavia, todas essas objeções não resultaram em uma mudança no exercício prático da interpretação: os profissionais do Direito continuam empregando os cânones, e a comunidade jurídica os aceita como expressão de um procedimento metodológico correto, simplesmente porque não há alternativas viáveis aos métodos clássicos. As prescrições legais jamais serão suficientes para a solução de boa parte dos casos. Mesmo assim, o operador jurídico deve orientar a sua decisão ao Direito vigente, sendo-lhe vedado tomar decisões na base de seu sentimento subjetivo de justiça. As regras metódicas têm a importante função de transmitir ao público a vinculação do intérprete ao texto normativo, o qual pode ser lacunoso, incompleto, vago etc., permitindo o controle do cumprimento desta exigência constitucional (MORLOK, 2012, p. 181 ss.).

A seguir, serão apresentadas as bases conceituais dos quatro critérios metódicos clássicos de interpretação jurídica, bem como as principais críticas que já foram formuladas a eles.

a) A letra da lei (interpretação literal ou gramatical) é, necessariamente, o ponto de partida do trabalho jurídico, justamente porque o texto legal transporta as prescrições vinculantes para o seu aplicador. Para identificar o sentido de uma palavra, o intérprete primeiro se valerá de sua intuição linguística, adquirida como integrante de uma sociedade em que se pratica um idioma. No entanto, o raciocínio a partir desta linguagem comum nem sempre é suficiente para a interpretação adequada de um texto legal, uma vez que o legislador também pode utilizar termos técnicos e especializados.

Em geral, o "sentido ainda possível da palavra" marca o limite da interpretação da lei, além do qual começa o âmbito da integração do Direito pelo Judiciário, que não 
encontra mais lastro no teor literal do texto legal e precisa ser baseada em outros parâmetros normativos. Sobretudo na área do Direito Penal, a teoria da "fronteira do teor da palavra” (Wortlautgrenze) põe limites à abrangência da interpretação. Já nas outras, são comuns as decisões judiciais que desconsideram o significado lexical de palavras legais quando há argumentos sustentados por outros meios metódicos ou até motivos extrajurídicos. A lacuna legal é tida como a precondição de uma legítima integração complementadora do Direito, sendo o instrumento mais utilizado para saná-la a analogia, que pode servir até para construir decisões contra legem, isto é, claramente fora dos limites do texto normativo. O mesmo acontece em sentido contrário na "redução teleológica”, que consiste na abertura de uma exceção em certas circunstâncias, apesar da nítida incidência de uma norma positiva que contempla o fato ocorrido (BYDLINSKI, 1982, p. 470 ss.).

A importância do teor literal da lei para uma interpretação adequada não deve ser sobre-estimada. Prova disso são normas que vigoram em diferentes idiomas oficiais (v.g., na Suíça ou na União Europeia), uma vez que conceitos legais traduzidos em diferentes línguas nunca terão exatamente o mesmo sentido para os seus leitores. Signos linguísticos não possuem um espaço fixo de referência que pode ser identificado de uma vez por todas; antes, a "semântica instável" é dominada pela pragmática do seu emprego pelos usuários. No Direito, esta “fixação de referência” para certas palavras é efetuada pela jurisprudência, pela doutrina e pela comunidade jurídica em geral, podendo haver necessidade de argumentar em favor de ou contra o uso de uma palavra em determinado sentido. O reconhecimento da falibilidade da interpretação literal e a instabilidade do significado dos termos jurídicos, contudo, não devem levar à descrença absoluta no elemento gramatical da exegese jurídica, como se este não tivesse importância na produção da decisão (MORLOK, 2012, p. 193 ss.).

É duvidoso se existe “o sentido literal” de uma expressão linguística vaga ou escura, cuja substância material sempre seria capaz de ser esclarecida. Em vez disso, um preceito legal deve ser considerado determinado enquanto não surjam, entre os atingidos por ele, dúvidas sobre o entendimento acertado. Essas opiniões divergentes desfazem o sentido arrazoado da palavra, colocando em seu lugar propostas acerca do seu entendimento "certo". Possíveis dúvidas podem ser racionalmente rechaçadas somente por meio de argumentos, o que faz com que uma tradição vitoriosa deva a sua continuidade à disputa por eles, não a si mesma e, menos ainda, a um pretenso "genuíno sentido literal” do texto legal (GAST, 1982, p. 303 ss.). No entanto, a forte influência da filosofia da linguagem sobre a teoria da interpretação ("giro linguístico") não causou o abandono dos métodos jurídicos, mas apenas o seu reposicionamento no sistema teórico dominante. ${ }^{7}$

Deve ser lembrado também que os juristas geralmente se preocupam bastante com o (pretenso) significado objetivo das normas, porque uma dependência total do sentido de acordo com o contexto de sua utilização prejudicaria sobremaneira "a segurança, a 
previsibilidade, o controle do fato social, que o direito dever propiciar" (CASTRO JÚNIOR, 2009, p. 42). Por consequência, "o significado literal é uma pressuposição muito forte na doutrina do Direito", sendo talvez "impossível entender o que modernamente se pensa ser o Direito sem se ter assumido, ao menos estrategicamente, a ideia de que há um significado literal das palavras das normas" (ob. cit., p. 79).

b) Em uma ordem jurídica desenvolvida e complexa, a unidade sistemática é um dos ideais mais elevados a serem perseguidos, acompanhado pelos postulados da consistência (= ausência de contradições) e da coerência (= estrutura interna de referência) (MORLOK, 2012, p. 188). Este fato é a base da interpretação sistemática. Qualquer norma legal está posta no seio de um conjunto regulatório, formado por regras e princípios inseridos da mesma lei, em leis hierarquicamente iguais, superiores ou inferiores, cuja leitura pode ganhar importância decisiva na interpretação de um dispositivo. É hoje universalmente aceito que as normas constitucionais (sobretudo os direitos fundamentais) podem exercer grande influência em relação a uma interpretação extensiva ou restritiva de um artigo do Código Civil ou de um permissivo da legislação urbanística, por exemplo.

Ao mesmo tempo, deve ficar claro que a alegação que certa interpretação de um termo jurídico se acha "conforme com o sistema” não passa de uma proposta, que pode convencer mais, ou menos, necessitando sempre de argumentação em seu favor. Não existe um sistema jurídico fechado e numerosos produtos legislativos não se deixam compreender de forma sistemática. Especialmente a interpretação a partir de normas principiológicas da Constituição costuma envolver a ponderação entre diferentes valores e interesses reconhecidos pela ordem jurídica. Esta abertura das opções argumentativas faz com que o resultado defendido deva ser bem arrazoado e sopesado, o que torna este tipo de interpretação mais complexo e sofisticado (MORLOK, 2012, p. 197).

c) Quando surgem dúvidas sobre o significado de um texto legal, faz sentido indagar sobre a intenção de seu autor e o contexto histórico de sua elaboração. Uma interpretação que pretenda ser "fiel ao legislador" deve incluir a consulta dos materiais legislativos que podem esclarecer o significado intencionado de certos termos, os fins específicos da norma, as alternativas de solução rejeitadas etc. Uma interpretação histórica mais genérica não se concentra na vontade manifestada pelos órgãos legislativos, mas tenta recapitular a situação social, política e econômica no momento da aprovação da lei. Ela ganha importância no caso de um maior lapso temporal entre a produção da norma e sua aplicação. O objetivo aqui não é a reprodução de uma (pretensa) vontade legislativa original, mas a sua relativização em função do contexto outrora dado (ex.: Código Penal brasileiro).

A indagação sobre os condicionantes históricos de uma norma dificilmente leva a indícios claros sobre a forma como ela deveria ser entendida e aplicada hoje. A interpretação genética, que tenta seguir a vontade do legislador, esbarra na objeção de que, 
nos complexos processos legislativos atuais, não há mais "uma vontade" legislativa a ser descoberta; o que interessa é somente o texto aprovado e não as pretensas vontades subjacentes. Outras críticas contra uma fixação nas intenções originais dos legisladores são a possível "petrificação da ordem jurídica" e a "dominação dos mortos sobre os vivos”. Em geral, a interpretação histórico-genética, que hoje serve mais como método complementar, passou a desconsiderar a vontade subjetiva dos feitores da lei, concentrando-se apenas na "vontade objetivada" do legislador, que se manifesta através do teor linguístico do próprio dispositivo legal e de seu "contexto de sentido" (MORLOK, 2012, p. 198 s.).

d) Muitas vezes, o fim da norma assume uma função decisiva na definição do significado de um dispositivo legal no caso concreto, uma vez que o Direito serve para produzir soluções adequadas para certos problemas. Ao contrário dos outros elementos metódicos, o teleológico não guarda relação direta com o texto legal, mas perquire sobre algo externo, isto é, a orientação instrumental da norma, o que atribui ao intérprete uma considerável liberdade na afirmação deste fim concreto e das suas consequências para o caso. No centro de atenção aqui não estão questões semânticas, a coerência do sistema ou as intenções do legislador, mas a responsabilidade do intérprete pelo alcance de um resultado correto e/ ou justo para o caso concreto a ser decidido. Por isso, o elemento teleológico certamente é o mais elástico dos cânones, o que o torna o preferido na prática da interpretação (MÜLLER; CHRISTENSEN, 2002, p. 99).

Os fins dos atos humanos são suas consequências decisivas, aquelas pelas quais aqueles são cometidos. A distinção entre o próprio fim de um ato e de suas consequências (principais ou acessórias) é sempre um ato de vontade subjetiva, uma vez que o fim não pode ser deduzido objetivamente do próprio ato. A norma, contudo, deve servir a um fim considerado razoável, que pode ser apresentado como tal; um discurso interpretativo sobre este fim normativo não pode ser arbitrário, antes precisa de uma fundamentação consistente que seja capaz de ser defendida contra possíveis contestações. Assim, o elemento teleológico da interpretação resguarda e aumenta a racionalidade da produção da decisão, uma vez que exige um convencimento argumentativo sobre o juridicamente correto (MORLOK, 2012, p. 202 ss.).

Para definir o fim da norma concreta, o intérprete pode seguir a (tradicional) teoria subjetiva, que pergunta pela vontade do legislador histórico, ou a teoria objetiva, que se tornou majoritária na metodologia jurídica da Alemanha. Esta linha entende que a finalidade da lei se desliga da intenção original de seu criador e deve ser fixada de acordo com as necessidades atuais e os valores sociais prevalecentes no momento de sua aplicação. É evidente que a teoria objetiva do fim da lei abre maiores espaços para o trabalho hermenêutico do aplicador da norma. Apesar das críticas contra esta vertente do método teleológico, ela corresponde melhor aos desafios de uma interpretação correta numa ordem jurídica constitucionalizada, que impõe a realização dos valores consagrados na Lei Maior em todos os ramos do Direito (HAGER, 2009, p. 32 ss.). Ao mesmo tempo, 
o correto emprego deste elemento metódico exigirá do intérprete um máximo de atitude restritiva, cautelosa e autocrítica (HASSEMER, 2007, p. 136s.).

Não existe uma ordem ou sequência predeterminada para a aplicação das diretivas metódicas clássicas. Em muitos casos, eles nem podem ser claramente distintos, mas se interpenetram, ficando em aberto se o resultado está mais lastreado em razões referentes ao sentido literal, à posição da norma no sistema como um todo, à gênese de sua elaboração ou ao fim normativo. Em uma escala maior, aspectos como os tradicionais cânones interpretativos, a concretização da norma, a jurisprudência anterior, as consequências da decisão e as ponderações de justiça prática não devem ser colocados um ao lado do outro, mas formam um nexo razoável dentro de um processo homogêneo de raciocínio (KRIELE, 1976, p. 329 s.).

\section{Os “MÉTODOS” JURÍdicos:}

\section{INSTRUMENTOS INDISPENSÁVEIS PARA INTERPRETAR O DIREITO}

Na prática dos tribunais e órgãos administrativos de vários países, os referidos "métodos” de interpretação jurídica, apesar das críticas teóricas formuladas nas últimas décadas, sempre têm funcionado: os operadores do Direito (administradores, procuradores, juízes, advogados etc.) continuam a se valer efetivamente deles para produzir as suas sentenças, petições e pareceres. Diedrichsen (1980, p. 29 ss.) chega a afirmar que um juiz que, no processo mental de formação da decisão, não se deixa orientar pelos métodos jurídicos, não consegue mais cumprir a sua tarefa, tornando-se "descontrolado feito um veículo sem condutor". Com efeito, quando uma ordem jurídica está em contradição com as condições e os postulados de sua metodologia tradicional, o profissional do Direito fracassará no dia a dia de seu trabalho prático ou atenderá às regras metódicas só aparentemente, o que não corresponde à realidade brasileira (CANARIS, 1983, p. 15).

O emprego das diretivas metódicas do Direito serve, antes de tudo, para delimitar e reduzir a arbitrariedade subjetiva do intérprete. Estabelecem-se regras com a intenção de nortear o processo de raciocínio jurídico e de separar os argumentos jurídico-constitucionais (ainda) legítimos dos (já) ilegítimos, o que torna as respectivas decisões e opiniões criticáveis. Esse fim, contudo, somente será alcançado "na medida em que regras metódicas são reconhecidas e consequentemente seguidas por parte da jurisprudência” e dos operadores jurídicos em geral (KRIELE, 1976, p. 24 ss.).

Essa situação tem especial relevância no Brasil, onde são pronunciadas quase diariamente decisões judiciais contraditórias, fato que não pode ser atribuído apenas ao sistema do controle difuso de constitucionalidade vigente no País. No próprio STF, que somente julga uma pequena parcela das lides em plenário e onde as decisões tomadas de forma monocrática, hoje, são a regra (VERÍSSIMO, 2008, p. 424 ss.), aumentam os casos em que os diferentes ministros aplicam as mesmas leis de forma diversa a fatos praticamente iguais. Isso se deve, sobretudo, à pré-compreensão diferenciada sobre a 
solução justa dos problemas subjacentes às lides, o que leva a uma escolha altamente instável dos métodos concretos, que o respectivo relator considera adequados para fundamentar o seu julgamento. O problema é que a pré-compreensão individual, que naturalmente varia, sofre pouca orientação e consolidação por parte da doutrina jurídica nacional sobre os métodos interpretativos, em que diferentes escolas se digladiam, sem causar, contudo, maiores efeitos em relação ao trabalho prático da aplicação do Direito.

Ainda que ninguém possa negar que sempre restam elementos irracionais no processo da tomada de decisões jurídicas, faz sentido esgotar ao máximo as possibilidades da argumentação racional. Isso leva da procura pela interpretação correta ao campo do raciocínio metódico, e assim contribui para o disciplinamento das valorações judiciais: considerações jurídicas são estruturadas por modelos de reflexão e divididas de acordo com pontos de vista racionais. "Aqui, os 'critérios de interpretação' afirmam-se como instrumentos argumentativos norteadores da discussão, como 'conceitos-chaves' que tornam acessíveis questões de interpretação e, por fim, de justiça, atribuindo-lhes um feitio conceitual específico, sem, contudo, conseguir solucioná-las plenamente” (ZIPPELIUS, 1996, p. 401).

Para Müller (2008, p. 77ss.), o abandono da ideia de métodos absolutos de interpretação não justifica bani-los do processo de concretização do Direito, sendo preferível reconhecer a sua legitimidade apenas relativa e a limitação de seu alcance, bem como utilizá-los em favor da racionalização e do controle na aplicação das leis. Os cânones, obviamente limitados na sua objetividade, atuam em função de uma "simplificação construtiva” e estabilizadora que serve, sobretudo, para ordenar, verificar e discutir melhor os aspectos e pontos de vista jurídicos. As regras interpretativas clássicas não são corpos estranhos conectados à lógica formal, mas sempre têm funcionado na práxis jurídica como "siglas de determinadas linhas de análise, de determinados tipos de pontos de vista materiais" (p. 91). Como marcas no caminho da concretização do Direito, elas fomentam a produção de decisões plausíveis por meio da exposição racional das razões.

Zaccaria (2004, 128 ss.) enfatiza que uma reflexão atenta sobre as condições do ato de compreensão na área do Direito mostra que "os vínculos constituídos pelas regras, os métodos, os cânones de interpretação dos textos, a dogmática jurídica, a comunidade dos intérpretes e dos juristas, e a própria dimensão da textualidade, não podem jamais eliminar totalmente a discricionariedade". Entretanto, a função normativo-descritiva dos meios metódicos contribui a estruturar e conter os espaços de liberdade do intérprete. Após séculos, a metodologia do Direito dispõe, hoje, de um arsenal muito rico de cânones e formas de raciocínio, isto é, de diretivas técnicas sobre a atribuição de sentido a enunciados normativos. $O$ fato de que estes sempre deixam margens de avaliação não significa que não sejam úteis e não garantam alguma racionalidade. Eles marcam as etapas que o intérprete deve perpassar em seu raciocínio 
para poder formular e expor uma argumentação convincente a respeito das opções interpretativas escolhidas (cf. ZACCARIA, 2004, 273 s.).

Ainda que a teoria da linguagem tenha acabado com a esperança por um conhecimento definitivamente assegurado na interpretação de textos normativos, os métodos jurídicos ainda podem conferir uma "segurança relativa" (RÖHL; RÖHL, 2008, p. 609). Seja lembrado também que, embora juízes normalmente raciocinem a partir dos elementos metódicos jurídicos, eles dificilmente falam ou discutem sobre aqueles por eles concretamente empregados. Deste fato deve ser separada a necessidade de convencer mediante argumentos: do juiz se espera que ele justifique o próprio resultado, não o uso de certo(s) método(s) (LEMBCKE, 2012, p. 86 ss.).

\section{Argumentação Jurídica a Partir do resultado desejado?}

A INTERAÇÃO ENTRE A PRÉ-COMPREENSÃO INICIAL E A FUNDAMENTAÇÃO NA BASE DOS ELEMENTOS METÓDICOS

Vimos que proceder metodicamente permite que outros possam recapitular e avaliar a obtenção do resultado. No raciocínio jurídico, método e resultado se relacionam em uma forma muito complexa, havendo uma dependência recíproca entre ambos no processo hermenêutico. Os métodos estruturam o processo de produção da decisão judicial e desoneram o juiz, visto que preexistem e não são criados para a solução de cada caso. Nisso jaz um considerável "potencial de racionalização", que beneficia não somente a fundamentação da decisão posterior, mas já influencia o processo de reflexão sobre o próprio ponto de partida (LEMBCKE, 2012, p. 86 s.).

No entanto, o método ao qual o intérprete dará preferência no caso concreto será escolhido, pelos menos parcialmente, em função de sua intuição ou de seu "sentimento jurídico" (Judiz), que lhe permite antecipar o resultado que considera o mais satisfatório (ENGISCH, 1983, p. 145). De modo semelhante à norma, que só pode ser compreendida em relação ao suporte fático (e vice-versa), o método apenas se deixa determinar já com vistas à sentença presumida. Também há uma pré-compreensão na questão do método, marcada não apenas pelo esboço de um caminho à solução do caso, mas pela própria decisão final, antecipando-se, de certa forma, o conteúdo do Direito. Mais uma vez, o círculo hermenêutico se mostra inelutável: o método, embora deva ser algo pré-dado, não pode ser determinado sem que se tenha, desde o início, certa précompreensão da solução adequada do caso (MASTRONARDI, 2001, p. 177 ss.).

Josef Esser (1972), na sua famosa obra sobre a relação entre a pré-compreensão e a escolha de método na produção da decisão jurídica, chegou a afirmar que os aplicadores do Direito utilizam os métodos clássicos apenas para justificar formalmente (de lege artis) as decisões que eles já tomaram antes, na base de outros critérios, resultantes de sua subjetiva pré-compreensão, que seria formada e alimentada por sua experiência profissional e convicção político-ideológica. Devemo-nos lembrar, porém, que 
determinada prática exercida por parte dos juízes não a justifica. A metódica jurídica é normativa: ela quer prescrever a forma de construção do resultado da interpretação do Direito, não apenas observar ou convalidar (maus) hábitos (DIMOULIS, 2011, p. 232 ss.). A vinculação dos tribunais (e outras instituições estatais) à lei exige deles uma interpretação que seja "metodologicamente limpa" e cujo caminho se deixe recapitular e controlar.

Qualquer “argumentação a partir do resultado” deve ser metodicamente vinculada, transparente e consistente. A escolha do método prevalecente não pode ser arbitrária, meramente subjetiva ou intuitiva, mas necessita de fundamentação racional. Em grau maior ou menor, o resultado influencia o método em todas as ciências, cujo conhecimento está sujeito à adequação do método ao objeto, a qual se revela apenas por meio da experiência. Não parece, portanto, exagerado afirmar que é o próprio objeto que determina os meios mediante os quais ele se torna acessível ao sujeito. Além do mais, a ciência jurídica está condicionada pela relação entre o método e o conteúdo material das normas vigentes. É preciso que o método e o resultado "se refiram um ao outro por meio de argumentos, para que eles se determinem mutuamente" (MASTRONARDI, 2001, p. 179). Destarte, o processo de interpretação necessita como pontos de apoio de diferentes "métodos", que sejam "controláveis em pequenos passos" (MÜLLER; CHRISTENSEN, 2002, p. 222).

Neste contexto, é importante a diferenciação de Ricoeur (2000, p. 83 ss.) entre os momentos da compreensão e da explicação como fases de um único processo interpretativo, unidas por uma "dialética correlativa": a inicial "captação ingênua de sentido do texto", chamada de conjectura, é seguida por "um modo sofisticado de compreensão apoiada em procedimentos explicativos”. Embora não haja regras para fazer boas conjecturas, existem métodos para validar as efetivamente realizadas, operando-se uma "transição da conjectura para a explicação", o que faz com que o próprio círculo hermenêutico seja formado pela conjectura e pela validação "enquanto abordagem subjetiva e objetiva ao texto" (ob. cit., p. 88 ss.). A lógica da validação permite "girar entre os limites do dogmatismo e do ceticismo", sendo "sempre possível argumentar a favor de ou contra uma interpretação, confrontar interpretações, arbitrar entre elas e procurar um acordo [...]" (RICOEUR, 2000, p. 91).

$\mathrm{Na}$ área do Direito, a distinção entre a tomada e a (posterior) apresentação da decisão frequentemente é utilizada para questionar a própria capacidade dos cânones interpretativos. De fato, a justificativa (escrita ou oral) da decisão jurídica normalmente não deixa transparecer dúvidas sobre o resultado e tampouco menciona aqueles motivos que se acham fora dos padrões comuns da argumentação jurídica (v.g., considerações sobre os efeitos da decisão). Mesmo assim, é descabido presumir que a fundamentação da decisão se resuma em um "cinismo organizado, dedicado à ocultação dos motivos verdadeiros”. Essas fundamentações norteiam, sim, as próprias decisões, disciplinando o intérprete/aplicador do Direito (RÖHL; RÖHL, 2008, p. 610 s.). 
Destarte, o círculo hermenêutico se estende ao âmbito da escolha dos métodos jurídicos: somente se saberá qual elemento ganha maior importância para o caso concreto no momento em que se afere em quanto ele contribui para a sua solução. Os cânones não desoneram o intérprete de uma valoração do conjunto; eles fixam "trilhos de guia" em que ele deve orientar a sua atuação e critérios segundo os quais pode ser avaliado o seu resultado. São aspectos norteadores do processo interpretativo cujo peso pode variar bastante em cada caso. Neste sentido, Mastronardi (2001, p. 174 ss.) enfatiza que o próprio método jurídico deve ser entendido como o "esforço de motivar uma pré-compreensão em um modo intersubjetivamente controlável” e que o processo de justificação metodicamente orientado corrige a pré-compreensão de um modo que esta se deixa legitimar na base do Direito material.

O intérprete-aplicador do Direito normalmente não achará a decisão justa por meio de um acesso direto a princípios ou razões "últimas", mas mediante um avanço gradual, no qual ele primeiro busca o sentido correto das regras legais possivelmente incidentes. As regras metódicas demarcam certos passos ou degraus do raciocínio interpretativo, os quais, contudo, não podem ser omitidos, sob pena de que aspectos importantes sejam esquecidos. Tal procedimento "passo a passo" permite uma verificação racional, ainda que a tomada de juízos de valor seja imprescindível (LARENZ, 1991, p. 151).

Assim, a hipótese inicial de um possível significado pode ser corrigida por sucessivas hipóteses que levam à adequação, melhoria ou até à substituição da hipótese originária”, o que acaba modificando a própria “expectativa de significado” do intérprete. Por isso, a tão citada pré-compreensão "tem um valor limitado ao momento heurístico da busca da hipótese de solução e representa somente uma parte (preparatória) da prática jurídica” (VIOLA; ZACCARIA, 2007, p. 188 s.). No mesmo sentido, Häberle (1978, p. 79 s.) sublinha que a pré-compreensão não é fator unilateral para determinar a escolha dos elementos metódicos da interpretação jurídica, uma vez que "os métodos retroagem em direção à pré-compreensão: eles a ensinam e formam no decorrer do tempo, tanto pelos resultados que causam concretamente quanto por sua atuação em conjunto". 8

A perspectiva retórica do Direito age de forma precipitada quando condena a metodologia clássica por sua pretensa "técnica de fundamentação de fachada". Não há desonestidade no ato do intérprete que se vale de um estilo descritivo para fundamentar sua decisão como se ela fosse resultado de um processo objetivamente norteado e livre de valorações próprias ou dúvidas. Antes, tal procedimento deve ser visto como forma refletida de apresentação que segue as regras de arte da retórica, integrada também por instruções da metodologia oficial. As "lendas de origem" (da decisão) que são narradas dessa forma representam meios imprescindíveis de interpretação que facilitam a compreensão do Direito (LAUNHARDT, 2001, p. 153 s.).

Neste diapasão, Alf Ross (2003, p. 169 ss.) observou que "graças a uma técnica de argumentação que foi desenvolvida como ingrediente tradicional da administração da 
justiça, o juiz aparenta que por meio de várias conclusões, sua decisão pode ser deduzida da verdadeira interpretação da lei”. Destarte, “o juiz atribui cortesmente à vontade real ou hipotética do legislador tudo aquilo que ele julga correto”, sendo preciso que ele saiba "justificar tecnicamente, mediante argumentos interpretativos, a solução jurídica que considera justa ou desejável” (ob. cit., p. 179 ss.). O autor deixa claro que, embora tais argumentos técnicos não revelem "as razões verdadeiras" da decisão, "a função dos métodos de interpretação é estabelecer limites à liberdade do juiz na administração da justiça, os quais determinam a área de soluções justificáveis” (ROSS, 2003, p. 183).

Os clamores por uma maior honestidade e completude da fundamentação das decisões jurídicas, na verdade, referem-se menos à documentação completa do processo de sua produção do que ao cumprimento de um esquema coerente de justificação que corresponda ao ideal de razoabilidade. Este não é apenas observado quando fundamentações são apresentadas nos moldes da aplicação dedutiva da lei, mas também quando elas se apoiam em uma análise dos efeitos da decisão ou no atendimento a regras discursivas. A aceitabilidade e a força de convencimento de uma fundamentação dependem da capacidade de o intérprete repassar à comunidade jurídica uma imagem da decisão que se enquadre bem no ambiente técnico específico das ideias de ordenamento e das expectativas dos interessados na decisão (LAUNHARDT, 2001, p. 154 s.).

Longe das exageradas expectativas de uma racionalidade plena, torna-se possível reconhecer os bons serviços prestados pela metodologia jurídica tradicional e desenvolver perspectivas para o seu melhoramento. O relativo sucesso desse padrão "pouco realista" de aplicação do Direito se deve ao fato de que a “'lenda de origem' do modelo de subsunção exige e promove um jeito de fundamentação que representa vinculação à lei e objetividade”. Os problemas de valoração e interpretação que surgem no caso concreto não são superados mediante um recurso direto a interesses, ao bem comum, à justiça ou aos prováveis efeitos da decisão, pois necessitam da "inclusão conceitual em premissas na forma de frases, as quais, por sua vez, devem achar o seu lugar de acordo com catálogos de topoi e esquemas de prova já estabelecidos" (LAUNHARDT, 2001, p. 155).

\section{Método JURídico E ARGUMENTAÇÃo: UMA IMBRICAÇÃO INSOFISMÁVEL}

No contexto da interpretação jurídica, argumentar significa "indicar razões, que deixam uma afirmação aparecer justificada, acertada ou, no mínimo, discutível” (LARENZ, 1991, p. 152). Para Alexy (2000, p. 301 ss.), os cânones interpretativos, ainda que não garantam que o julgador de um caso chegue por meio deles ao único resultado correto, são mais do que apenas topoi, "direções de perguntar" ou meros "instrumentos de legitimação secundária de uma decisão tomada e fundamentada de outra maneira”. Como específicas formas argumentativas, eles caracterizam a própria estrutura da argumentação jurídica, isto é, a gramática do seu discurso. O autor alega que a "exigência 
de saturação dos cânones" assegura a racionalidade de seu emprego, de modo que não basta a mera afirmação de que determinada interpretação resulte do teor linguístico de uma lei, de sua origem ou de seu fim. Por isso, sempre é necessário indicar "premissas empíricas ou normativas cuja verdade ou retidão a qualquer momento pode ser objeto de novas discussões".

Os tradicionais recursos metodológicos da interpretação (especialmente os quatro cânones) são nada mais (e nada menos) do que argumentos utilizados no debate jurídico para alcançar a convicção ou persuasão dos participantes (GARCÍA AMADO, 2004, p. 51). Nessa linha, os cânones interpretativos são vistos como "a sequência metódica de degraus do raciocínio jurídico que é mais adequada à lei” (RAISCH, 1988, p. 70 ss.), estabelecendo uma medida mais firme para aferir considerações tópicas, associativas, orientadas pelos efeitos da decisão, norteados pelo sentimento jurídico etc. O uso desses aspectos metódicos na interpretação não consegue evitar as indeterminações do Direito, mas logra efeito em diminuí-las. Na prática, os cânones são integrados nos diferentes modos ou "jogos" de argumentação, havendo uma combinação entre modos de raciocínio tradicionais e teórico-argumentativos. Somente o discurso racional abre os caminhos para uma teoria moderna de justiça, cujo resultado, na expressão de Peczenik, “é um sistema móvel de boas razões” (RAISCH, 1988, p. 81).

É importante formular o trato de questões jurídicas como um problema de argumentação racional, e não de um "conhecimento correto". O principal ponto fraco da tradicional Metodologia do Direito - e razão por inúmeras, acertadas críticas - está na sua recusa a abdicar desta "pretensão cognitiva” de maneira convincente. Nos espaços que ultrapassam a cognição não reinam, necessariamente, decisionismo e arbitrariedade, uma vez que as decisões devem ser racionalmente fundamentadas (NEUMANN, 2001 , p. 241 ss.). Assim, a visão tradicional da interpretação jurídica como um esquema fixo ou "pressuposto algoritmo metódico" foi superada pelo entendimento de que ela deve procurar sempre os "modos metodologicamente específicos" para enfrentar o desafio da realização do Direito por meio de uma interpretação não apenas semântica, mas, antes de tudo, prático-normativa e problemático-concreta, que produza decisões corretas e justas para solucionar os problemas de casos concretos (CASTANHEIRA NEVES, 1993, p. 106, 127).

Os métodos da interpretação jurídica formam um "andaime flexível de argumentação" (BRUGGER, 1994, p. 31). A sua estrutura representa um espaço "entre vínculo e liberdade, entre rigidez e flexibilidade, entre o exercício do risco e da fidelidade; é processo dialético entre, por um lado, a lógica do provável e do razoável e, por outro, a lógica do necessário e do construtivo" (ZACCARIA, 2004, p. 276). Dependendo dos fatos e das normas incidentes, a utilização de cada regra metódica pode fornecer argumentos de força bastante diferenciada: um pode falar em favor de determinada solução, outro contra. Somente uma ponderação entre estes argumentos metódicos pode levar a uma decisão racional e bem justificada. É claro que a capacidade de convencimento 
de um argumento interpretativo depende largamente de diversos interesses e das intuições morais culturalmente preestabelecidos (COING, 1959, p. 23; SEELMANN, 2007, p. 174).

A argumentação jurídica, contudo, não é mero elemento da metódica do Direito, mas cumpre uma tarefa própria que ultrapassa o emprego dos métodos. Na forma da fala arrazoada, ela é a chave de garantia da correição/retidão de decisões, expressando uma profunda mudança de perspectivas em relação à metódica tradicional, já que a fundamentação não é mais vista como "explicação da aplicação" do Direito, mas como a sua própria aplicação (SCHMITT GLAESER, 2004, p. 143). A questão central da metódica é a pergunta pelos "parâmetros normativos intersubjetivamente válidos" que podem ser racionalmente identificados e legitimamente introduzidos no processo da produção do Direito (BYDLINSKI, 1982, p. 183). Além das normas positivadas, estes incluem também razões, fins ou motivos legais, a ratio legis, a avaliação dos interesses pelo legislador, suas valorações, os princípios jurídicos, a natureza das coisas etc. (ob. cit., p. 256).

Para Rottleuthner (1973, p. 253 s.), é a característica (e problemática) da argumentação jurídica que nela se usa uma pletora de "instâncias argumentativas", isto é, empíricas, normativas, hermenêuticas e descritivas de conceitos. A plausibilidade é alcançada menos por uma estrita dedução lógico-formal de normas legais do que pela apresentação dessas instâncias e a (aparente) orientação metódica do intérprete na sua identificação. Qualquer argumentação já pressupõe o consenso sobre normas: do ponto de vista lógico, elas fundamentam a comunicação, podendo ser questionadas apenas de forma fictícia ou abordadas por teóricos da argumentação. Na área jurídica, o temido sincretismo metodológico seria o próprio elemento do trabalho de justificação, com o fim de tornar um julgamento plausível e tirá-lo da aparência de um mero "decreto silogístico".

Quem nega ser possível arrazoar objetivamente a retidão de decisões jurídicas em virtude da multiplicidade de ideias divergentes sobre "o correto" não está à altura da práxis argumentativa do Direito, que sempre pressupõe - e, em face das expectativas dos endereçados, deve pressupor - uma "pretensão de correição" objetiva. Os céticos nutrem uma visão inadequada da retidão de decisões por ligar a este conceito expectativas que vão além daquilo que se pode esperar no contexto de um pensamento decisório. Este jamais terá por objeto uma correção absoluta e comprovada, mas apenas uma justificada, que pretende convencer mais do que as opiniões alternativas. Apesar de sua pluralidade e da avançada positividade de seu Direito, as sociedades modernas também funcionam na base de um âmbito não questionado de suposições básicas e experiências comuns de sentido, a partir de que os esforços por uma correição objetiva de decisões jurídicas podem se orientar e estruturar. Além disso, há um largo espectro entre, em um lado, argumentos autoevidentes e, no outro, razões polêmicas, o que permite a formação de convicções graduais (GARRN, 1986, p. 78 ss.). 
Já Popper (2004, p. 77 s.) mostrou que uma mera “intuição intelectual”, resultado de repetidas experiências de pessoas que por meio delas geraram um sentimento para entender determinadas coisas, não serve para fundamentar a verdade de qualquer ideia ou tese, independentemente da intensidade com que o pesquisador julgue algum resultado "autoevidente". Essas intuições podem somente incentivar a procura por argumentos, o que leva tanto a descobertas quanto a fracassos. A ciência, na visão do filósofo, não pergunta como alguém chegou a seus resultados, mas apenas se interessa pelos argumentos capazes de ser analisados e questionados por qualquer um que tenha conhecimentos suficientes na respectiva matéria.

Em geral, observa-se um deslocamento do interesse de uma metodologia jurídica como teoria da decisão correta em direção de uma teoria da argumentação jurídica como disciplina que se ocupa dos padrões de uma justificação correta. A própria prática jurídica, hoje em dia, costuma discutir intensivamente as questões polêmicas, muitas vezes com referência às opiniões divergentes na doutrina: o fundamento da auctoritas cede lugar à veritas. O ideal perseguido na argumentação jurídica é a legitimidade por meio da retidão/correção (NEUMANN, 2008, p. 78 s.).

A motivação da sentença do juiz, aqui entendida como cristalização da argumentação jurídica, deve mostrar que a decisão é correta, mas não serve para provar que o julgador a tomou em virtude de motivações corretas, que podem ser pessoais, corporativas, políticas, religiosas etc. Valem somente as razões pronunciadas, não as internas: a sentença baseada em argumentos fracos não se torna melhor em razão dos motivos nobres do juiz. Igualmente, a decisão convincentemente arrazoada não perde vigor por ser fruto da atitude política ou religiosa do julgador. A argumentação jurídica não serve para revelar os "verdadeiros" motivos que nortearam o processo interno da decisão, mas para aportar razões convincentes para a sua aceitação intersubjetiva (NEUMANN, 2008, p. 87 s.).

\section{À GUISA DE CONCLUSÃO}

A retórica e a argumentação não podem substituir a metódica jurídica, pois somente esta anda suficientemente próxima às decisões tomadas em um Estado Democrático de Direito. Os cânones metódicos clássicos não garantem resultados certos ou verdadeiros, mas representam importantes meios de apoio ao trabalho jurídico. Reconhecer este fato pode levar a uma problematização e utilização mais racional desses elementos de interpretação. Os cânones devem ser entendidos menos como regras metodológicas determinantes do que orientações e exortações que apontam em direção a certas perguntas, já que elas mesmas deixam em aberto quando e como devem ser utilizadas em um caso concreto. A metodologia jurídica fornece aspectos e fórmulas que ajudam a estruturar melhor o processo de interpretação, tornando-o racionalmente controlável (KOLLER, 1997, p. 211). 
Os cânones metódicos representam "instâncias argumentativas pouco problemáticas” (ROTTLEUTHNER, 1973, p. 30 s.), porém dificilmente pronunciadas de forma expressa; parte dos profissionais do Direito não as emprega de maneira consciente. Mesmo assim, elas existem, formando uma condição conceitual da ciência jurídica, embora a teoria do Direito não consiga fornecer ao pesquisador um aparato metódico acabado que garanta a segurança de alcançar sempre resultados corretos. Na verdade, o treinamento metódico do aplicador do Direito leva a nada mais do que a sua crescente autocompreensão, à consciência no uso das normas metodológicas que norteiam a teoria jurídica e à reflexão sobre estas (AARNIO, 1979, p. 6 s.).

Nesse raciocínio, "os métodos tradicionais de interpretação são basicamente recursos de justificação e sua utilização deve ser examinada considerando-se a interpretação no Direito como um processo de decisão em que cabe distinguir decisões racionalmente fundamentadas de decisões arbitrárias" (VERNENGO, 2000, p. 254). Não existe uma verdade ou "retidão objetiva" jurídica fora do procedimento metódico de interpretação; uma decisão correta precisa ser fundamentada de acordo com os cânones: muitas vezes além deles, mas nunca sem eles. O que, no fundo, vale é a "completude da reflexão e argumentação no processo interpretativo" (KAUFMANN, 1971, p. 102).

Os elementos interpretativos "estruturam uma parte daquelas figuras argumentativas, por meio das quais produzimos - pelos menos para o círculo dos juristas - a capacidade de consenso para a plausibilidade de concatenações justificativas" (ESSER, 1975, p. 555 s.). A aceitação tão boa desses critérios na prática dos profissionais do Direito durante séculos se deve também ao fato de que os argumentos neles condensados realmente são importantes. Por isso, os esforços de aportar argumentos materiais plausíveis e o questionamento crítico continuam tendo grande relevância para a apresentação metodológica da decisão judicial nos moldes clássicos.

Admitindo a impossibilidade de uma objetividade absoluta na interpretação do Direito, a hermenêutica moderna pretende submeter o raciocínio jurídico a um controle intersubjetivo. Nessa tentativa, os cânones não constituem regras para prescrição de determinado procedimento metódico, mas apontam somente os tópicos que devem ser considerados no processo interpretativo. Por isso, a diferença entre metódica e arte na hermenêutica jurídica é mais gradual (quantitativa) do que qualitativa (GIZBERT-STUDNICKI, 1987, p. 350 s.).

Sem dúvidas, os cânones clássicos da metódica jurídica sempre serviram também para camuflar os verdadeiros motivos de inúmeras decisões tomadas por órgãos públicos. No trabalho diário da aplicação do Direito, a notória escassez dos recursos tempo e informação costuma inviabilizar uma exploração das camadas mais profundas da obtenção das decisões. Talvez, o sucesso prático dos quatro cânones metódicos se deve a sua aptidão de finalizar, de forma aceitável para a comunidade jurídica, um processo de discussão interpretativa, valendo-se para tanto de uma abordagem nitidamente 
superficial, a qual, porém, é amplamente compartilhada, justamente por manter as questões mais profundas em latência (MORLOK, 2012, p. 209).

Todas as críticas não retiram o seu valor argumentativo na produção de sentenças, petições e pareceres. Os elementos metódicos do Direito não são panaceia, nem comparáveis aos métodos das ciências exatas; são ferramentas, canais de raciocínio e esquemas de argumentação racional, e como tais devem ser respeitados e estudados pela teoria, inclusive no Brasil do século XXI.

: ARTIGO APROVADO (22/01/2014) : RECEBIDO EM 16/04/2013

\section{NOTAS}

1 Expressão desta tendência é o título do n. 32 da tradicional revista justeórica alemã Rechtstheorie: “Vom Scheitern und der Wiederbelebung juristischer Methodik im Rechtsalltag" (= "Do fracasso e da reanimação da metódica jurídica no dia a dia do Direito").

2 Manoel M. Peixinho (2010, p. 196 s.) menciona as "técnicas de interpretação herdadas de Savigny" quando apresenta a "teoria concretizadora" de Friedrich Müller, da qual ele discorda. Ricardo M. Freire Soares (2010, p. 175 ss.) faz apenas referência indireta aos cânones, reproduzindo trechos de algumas decisões do STF sobre a temática. A famosa obra de Carlos Maximiliano (1873-1960) sobre Hermenêutica e aplicação do Direito (2010), o livro brasileiro mais tradicional sobre o assunto, não trata dos métodos clássicos de forma organizada, tecendo apenas algumas observações isoladas ao longo do texto (p. 91s., 99, 104s., 112ss., 124ss.)

3 Vide também Souza Neto; Sarmento (2012, p. 410 ss.). Lôbo Torres (2006) fornece uma profunda análise de positivação, conteúdo e alcance dos métodos clássicos para a interpretação das normas do Direito Tributário.

4 É intencional o uso do termo metódica; este não corresponde ao significado de metodologia, que "é a doutrina sobre os métodos, isto é, a visão que se tem desses caminhos e as tentativas de controlá-los”. Diferentemente, a "metódica é o estudo da relação entre esses métodos e essas metodologias, para compreendê-los” (ADEODATO, 2009, p. 38).

5 Em relação à metodologia eclética da jurisdição constitucional alemã pós-guerra, Kriele (1976, p. 50) presume que tenha sido uma "estreiteza irrealista inerente à própria teoria das regras de arte e dos procedimentos lógicos que acabou libertando o juiz, em virtude de uma desconsideração das necessidades práticas”. Ele compara a situação com a canalização de um rio, que somente seria viável mediante a construção de um novo leito suficientemente largo para conduzi-lo; caso o leito for estreito demais, o rio transbordará as margens, resultando na perda total do controle sobre suas águas.

6 O famoso cânon de Friedrich Karl von Savigny (1779-1861) incluía os elementos da interpretação gramatical, lógica, sistemática e histórica, rechaçando o "método" teleológico, uma vez que o fim da norma somente poderia ser aperfeiçoado pelo legislador, mas nunca pelo juiz (MÜLLER; CHRISTENSEN, 2002, p. 99). Mesmo assim, a grande maioria dos autores, hoje, inclui o elemento teleológico no "cânon clássico" de interpretação do Direito, certamente em virtude da importância da obra de Rudolf von Jhering (1818-1892), a partir do famoso livro A finalidade do Direito (Der Zweck im Recht), de 1883. 
7 A teoria tradicional de interpretação entendia que o significado de um termo legal se produz por sua relação para com um ente objetivo extralinguístico - uma "verdade preexistente" ou uma "essência", que reside em todas as coisas assinaladas pela palavra. O giro pragmático-linguístico na teoria interpretativa levou ao entendimento de que a linguagem não representa algo existente na realidade, mas que o significado de uma expressão idiomática se produz, intersubjetivamente, na relação entre locutores que se comunicam com base em certas regras. Essa linha, baseada em Wittgenstein, considera a ciência do Direito um "jogo de linguagem especial", cujos participantes concordam a respeito da justificação de "pretensões de validade normativas". Para poder participar desse jogo, os operadores jurídicos aprendem de recorrer a cânones metódicos, precedentes, opiniões doutrinárias, as prováveis consequências da decisão etc. (HERBERT, 1995, p. 206 s.). De qualquer forma, os cânones possuem sua importância prática, e seu uso é necessário para participar da interpretação jurídica institucionalizada.

8 Para o autor, a pré-compreensão (Vorverständnis) encontra a sua “correspondência dialética" na "pós-compreensão" (Nachverständnis), o que enfatiza a importância da dimensão temporal para a compreensão da norma; esta, por sua vez, "é aberta para ambos os lados (fins) e, ao mesmo tempo, 'dirigida'”. Assim, "os múltiplos processos de interpretação constitucional se desdobram 'entre’ pré- e pós-compreensão” (HÄBERLE, 1978, p. 80).

\section{REFERÊNCIAS BIBLIOGRÁFICAS}

AARNIO, Aulis. Denkweisen der Rechtswissenschaft: Einführung in die Theorie der rechtswissenschaftlichen Forschung. Wien, N. York: Springer, 1979.

ADEODATO, João Maurício. A retórica constitucional: sobre tolerância, direitos humanos e outros fundamentos éticos do Direito positivo. São Paulo: Saraiva, 2009.

ALEXY, Robert. Begriff und Geltung des Rechts. 4. ed. Freiburg/München: Karl Alber, 2005.

Theorie der juristischen Argumentation: Die Theorie des rationalen Diskurses als Theorie der

juristischen Begründung. Frankfurt a.M.: Suhrkamp, 2000.

BARROSO, Luís Roberto. Curso de Direito Constitucional. 2. ed. São Paulo: Saraiva, 2010.

BONAVIDES, Paulo. Curso de Direito Constitucional. 18. ed. São Paulo: Malheiros, 2006.

BRUGGER, Winfried. Konkretisierung des Rechts und Auslegung der Gesetze. Archiv des öffentlichen Rechts (AöR), Bd. 119, Tübingen: Mohr, p. 1-34, 1994.

BYDLINSKI, Franz. Juristische Methodenlehre und Rechtsbegriff. Wien, N. York: Springer, 1982.

CAMPILONGO, Celso F. Interpretação do Direito e movimentos sociais. Rio de Janeiro: Elsevier, 2012.

CANARIS, Claus-Wilhelm. Systemdenken und Systembegriff in der Jurisprudenz: entwickelt am Beispiel des deutschen Privatrechts. 2. ed. Berlin: Duncker\&Humblot, 1983.

CANOTILHO, José Joaquim Gomes. Direito Constitucional e Teoria da Constituição. Coimbra: Almedina, 1997.

CASTANHEIRA NEVES, A. Metodologia jurídica: problemas fundamentais. Coimbra: Coimbra Editora, 1993.

CASTRO JÚNIOR, Torquato. A pragmática das nulidades e a teoria do ato jurídico inexistente. São Paulo: Noeses, 2009. CATÃO, Adrualdo. Decisão jurídica e racionalidade. Maceió: edUFAL, 2007.

COING, Helmut. Die juristischen Auslegungsmethoden und die Lehren der allgemeinen Hermeneutik. Köln/Opladen: Westdeutscher Verlag, 1959.

DIEDRICHSEN, Uwe. Methodenlehre und praktische Jurisprudenz. In: IMMENGA, Ulrich (Ed.).

Rechtswissenschaft und Rechtsentwicklung. Göttingen: Otto Schwartz, p. 17-31, 1980.

DIMOULIS, Dimitri. Sentidos, vantagens cognitivas e problemas teóricos do formalismo jurídico. In:

MACEDO JR., R.; BARBIERI, C. (Orgs.). Direito e interpretação: racionalidade e instituições. São Paulo:

Saraiva, p. 213-242, 2011.

ENGISCH, Karl. Introdução ao pensamento jurídico. Tradução J. B. Machado. 6. ed. Lisboa: C. Gulbenkian, 1983. ESSER, Josef. Bemerkungen zur Unentbehrlichkeit des juristischen Handwerkszeugs. Juristenzeitung (JZ), p. $555-558,1975$.

ESSER, Josef. Vorverständnis und Methodenwahl in der Rechtsfindung. Rationalitätsgrundlagen richterlicher Entscheidungspraxis. Frankfurt a.M.: Athenäum Fischer, 1972.

FERRAZ JÚNIOR, Tércio Sampaio. A ciência do Direito. São Paulo: Atlas, 1980.

FORSTHOFF, Ernst. Zur Problematik der Verfassungsauslegung. Stuttgart: Kohlhammer, 1961. 
GARCÍA AMADO, Juan Antonio. Interpretación e argumentación jurídica. San Salvador: Consejo Nacional de la Judicatura, 2004.

GARRN, Heino. Zur Rationalität rechtlicher Entscheidungen. Stuttgart: Franz Steiner, 1986.

GAST, Wolfgang. Recht als ius argumentandi. In: BALLWEG, O.; SEIBER, T.-M. (Eds.). Rhetorische Rechtstheorie.

Freiburg/München: Karl Alber, p. 297-320, 1982.

GIZBERT-STUDNICKI, Tomasz. Das hermeneutische Bewusstsein der Juristen. Rechtstheorie, n. 18, Berlin:

Duncker\&Humblot, p. 344-367, 1987.

GRAU, Eros Roberto. Ensaio e discurso sobre a interpretação/aplicação do Direito. 5. ed. São Paulo: Malheiros, 2009. HÄBERLE, Peter. Hermenêutica constitucional - A sociedade aberta dos intérpretes da Constituição. Tradução Gilmar F. Mendes. Porto Alegre: Sergio Antonio Fabris Editor, 1997.

HÄBERLE, Peter. Zeit und Verfassung. Verfassung als öffentlicher Prozess. Berlin: Duncker\&Humblot, p. 59-92, 1978. HAGER, Günter. Rechtsmethoden in Europa. Tübingen: Mohr Siebeck, 2009.

HASSEMER, Winfried. Juristische Methodenlehre und richterliche Pragmatik. In: Erscheinungsformen des modernen Rechts. Frankfurt a.M.: Vittorio Klostermann, p. 119-151, 2007.

HAVERKATE, Görg. Gewißheitsverluste im juristischen Denken. Zur politischen Funktion der juristischen Methode. Berlin: Duncker\&Humblot, 1977.

HERBERT, Manfred. Rechtstheorie als Sprachkritik: zum Einfluß Wittgensteins auf die Rechtstheorie. Baden-Baden: Nomos, 1995.

HOCHHUT, Martin. Methodenlehre zwischen Staatsrecht und Rechtsphilosophie. In: KRAWIETZ, W.;

MORLOK, M. (Eds.). Vom Scheitern und derWiederbelebung juristischer Methodik im Rechtsalltag - Ein Bruch zwischen Theorie und Praxis? Berlin: Duncker\&Humblot, p. 227-238, 2001.

KAUFMANN, Arthur. Die Geschichtlichkeit des Rechts im Licht der Hermeneutik. In: KAUFMANN, A. (Ed.).

Rechtstheorie - Ansätze zum einem kritischen Rechtsverständnis. Karlsruhe: C. F. Müller, p. 81-102, 1971.

KELSEN, Hans. Teoria pura do Direito. Tradução J. B. Machado. Coimbra: Arménio Amado, 1962, v. II.

KOLLER, Peter. Theorie des Rechts: eine Einführung. 2. ed. Wien usw.: Böhlau Verlag, 1997.

KRIELE, Martin. Theorie der Rechtsgewinnung: entwickelt am Problem der Verfassungsinterpretation. 2. ed. Berlin: Duncker \& Humblot, 1976.

KUHLEN, Lothar. Wertfreiheit in der Jurisprudenz? (Diskussionsbeitrag). In: HILGENDORF, Ernst; KUHLEN,

L. Die Wertfreiheit in der Jurisprudenz. Heidelberg: C. F. Müller, p. 33 ss., 1999.

LARENZ, Karl. Methodenlehre der Rechtswissenschaft. 6. ed. Berlin usw.: Springer, 1991.

LAUNHARDT, Agnes. Methodenlehre aus rechtsrethorischer Perspektive: Abschied von der Normativität? In: KRAWIETZ, W.; MORLOK, M. (Eds.). Vom Scheitern und der Wiederbelebung juristischer Methodik im Rechtsalltag. Berlin: Duncker\&Humblot, p. 141-157, 2001.

LEMBCKE, Oliver W. Urteilskraft in der Praxis des Bundesverfassungsgerichts. In: GABRIEL, G.; GRÖSCHNER, R. (Eds.). Subsumtion: Schlüsselbegriff der juristischen Methodenlehre. Tübingen: Mohr Siebeck, p. 73-107, 2012. LUHMANN, Niklas. Das Recht der Gesellschaft. Frankfurt a.M.: Suhrkamp, 1995.

MADEIRA FILHO, Wilson. O hermeneuta e o demiurgo: presença da alquimia no histórico da interpretação jurídica. In: BOUCAULT, C.; RODRIGUEZ, J. (Org.). Hermenêutica plural. São Paulo: Martins Fontes, p. 45100, 2002.

MAGALHÃES, Juliana N. Interpretando o direito como um paradoxo: observações sobre o giro hermenêutico da ciência jurídica. In: BOUCAULT, C.; RODRIGUEZ, J. (Org.). Hermenêutica plural. São Paulo: Martins Fontes, 2002.

MASTRONARDI, Philippe. Juristische Methode und Rechtstheorie als Reflexionen des Rechtsverständnisses. In: SENN, Marcel; FRITSCHI, Barbara (eds.). Rechtswissenschaft und Hermeneutik. Stuttgart: Franz Steiner, p. 97-110, 2009

MASTRONARDI, Philippe. Juristisches Denken: eine Einführung. Bern usw.: Haupt (UTB), 2001.

MAXIMILIANO, Carlos. Hermenêutica e aplicação do Direito. 19. ed. Rio de Janeiro: Forense, 2010.

MEDINA, Diego Lopes. Hermenêutica e linguagem na teoria do direito. In: MACEDO JR., R.; BARBIERI, C. H. (Orgs.). Direito e interpretação: racionalidade e instituições. São Paulo: Saraiva, p. 155-192, 2011.

MENDES, Gilmar Ferreira; COELHO, Inocêncio Mártires; BRANCO, Paulo Gustavo Gonet. Curso de Direito Constitucional. 2. ed. São Paulo: Saraiva, 2008.

MORLOK, Martin. Die vier Auslegungsmethoden - was sonst? In: GABRIEL, G.; GRÖSCHNER, R. (Eds.). Subsumtion: Schlüsselbegriff der juristischen Methodenlehre. Tübingen: Mohr Siebeck, p. 179-214, 2012.

MÜLLER, Friedrich. Teoria estruturante do Direito. Tradução P. Naumann e A. de Souza. São Paulo: Revista dos Tribunais, 2008.

MÜLLER, Friedrich; CHRISTENSEN, Ralph. Juristische Methodik - Band 1. Grundlagen Öffentliches Recht. 8. ed. Berlin: Duncker\&Humblot, 2002. 
NEUMANN, Ulfrid. Juristische Methodenlehre und Theorie der juristischen Argumentation. In: KRAWIETZ, W.; MORLOK, M. (Eds.). Vom Scheitern und der Wiederbelebung juristischer Methodik im Rechtsalltag. Berlin: Duncker \& Humblot, p. 239-255, 2001.

NEUMANN, Ulfrid. Recht als Struktur und Argumentation. Baden-Baden: Nomos, 2008.

PEIXINHO, Manoel Messias. As teorias e os métodos de interpretação aplicados aos direitos fundamentais: doutrina e jurisprudência do STF e do STJ. Rio de Janeiro: Lumen Juris, 2010.

POPPER, Karl R. Karl Popper Lesebuch. Hrsg.: D. Miller. 2. ed. Tübingen: Mohr Siebeck, 2004.

RAISCH, Peter. Vom Nutzen der überkommenen Auslegungskanones für die praktische Rechtsanwendung. Heidelberg: C. F. Müller, 1988.

RICOEUR, Paul. Teoria da interpretação. O discurso e o excesso de significação. Lisboa: Edições 70, 2000.

RÖHL, Klaus; RÖHL, Hans. Allgemeine Rechtslehre. 3. ed. Köln/München: Carl Heymanns, 2008.

ROSS, Alf. Direito e Justiça (1958). Tradução Edson Bini. Bauru/SP: Edipro, 2003.

ROTTLEUTHNER, Hubert. Richterliches Handeln - Zur Kritik der juristischen Dogmatik. Frankfurt a.M.: Fischer Athenäum, 1973.

RÜTHERS, Bernd. Rechtstheorie: Begriff, Geltung und Anwendung des Rechts. München: C. H. Beck, 1999. SCHELSKY, Helmut. Die Soziologen und das Recht. Opladen: Westdeutscher Verlag, 1980.

SCHILD, Wolfgang. Juristische Methode als Mittel der politischen Macht. In: HORN, Norbert (Ed.).

Europäisches Rechtsdenken in Geschichte und Gegenwart. Festschrift für Helmut Coing zum 70. Geburtstag - Band I. München: C. H. Beck, p. 413-432, 1982.

SCHMITT GLAESER, Alexander. Vorverständnis als Methode: eine Methodik der Verfassungsinterpretation unter besonderer Berücksichtigung U.S.-amerikanischen Rechtsdenkens. Berlin: Duncker \& Humblot, 2004.

SEELMANN, Kurt. Rechtsphilosophie. 4. ed. München: C. H. Beck, 2007.

SILVA, Virgílio Afonso da. Interpretação constitucional e sincretismo metodológico. In: SILVA, Virgílio Afonso da (Org.). Interpretação constitucional. São Paulo: Malheiros, p. 115-143, 2005.

SILVA, José Afonso da. Curso de Direito Constitucional positivo. 22. ed. São Paulo: Malheiros, 2003.

SOARES, Ricardo M. Freire. Hermenêutica e interpretação jurídica. São Paulo: Saraiva, 2010.

SOUZA NETO, Cláudio Pereira de; SARMENTO, Daniel. Direito Constitucional: teoria, história e métodos de trabalho. Belo Horizonte: Fórum, 2012.

STRAUCH, Hans-Joachim. Theorie-Praxis-Bruch - aber wo liegt das Problem? In: KRAWIETZ, W.;

MORLOK, M. (Eds.). Vom Scheitern und der Wiederbelebung juristischer Methodik im Rechtsalltag. Berlin:

Duncker\&Humblot, p. 197-209, 2001.

STRECK, Lenio. Hermenêutica e (m) crise. 10. ed. Porto Alegre: Livraria do Advogado, 2011.

TORRES, Ricardo Lôbo. Normas de interpretação e integração do Direito Tributário. 4. ed. Rio de Janeiro: Renovar, 2006. VELASCO, Rogelio L.; GUTIÉRREZ, Lucila C. Las diretivas de interpretación jurídica. México: Fontamara, 2011. VERÍSSIMO, Marcos Paulo. A Constituição de 1988, vinte anos depois: Suprema Corte e ativismo judicial "à brasileira”. Revista DireitoGV, n. 8, São Paulo, jul.-dez. p. 407-440, 2008.

VERNENGO, Roberto J. Interpretación del Derecho. In: GARZÓN VALDÉS, Ernesto; LAPORTA, Francisco J. (Eds.). El derecho y la justicia. 2. ed. Madrid: Trotta, p. 239-265, 2000.

VIOLA, Francesco; ZACCARIA, Giuseppe. Derecho e interpretación. Elementos de teoría hermenéutica del Derecho. Tradução A. Cebeira et al.. Madrid: Dykinson, 2007.

WARAT, Luís Alberto. Introdução geral ao Direito - I. Porto Alegre: Sergio A. Fabris, 1994.

ZACCARIA, Giuseppe. Razón jurídica e interpretación. Compilação: Ana Messuti. Cizur Menor Navarra:

Thomson Civitas, 2004.

ZIPPELIUS, Reinhold. Recht und Gerechtigkeit in der offenen Gesellschaft. 2. ed. Berlin: Duncker\&Humblot, 1996.

Andreas J. Krell

UFAL - Faculdade de Direito Campus A. C. Simões Av. Lourival de Melo Mota, s/n Tabuleiro dos Martins - 57072-900

Maceió - AL - Brasil akrellauol.com.br
Doutor em Direito Pela Freie Universität Berlin

Professor Associado e Diretor da Faculdade de Direito da Universidade Federal de Alagoas Pesquisador bolsista do CNPQ 